\title{
Cisapride treatment for gastro-oesophageal reflux in children (Review)
}

\author{
Augood C, MacLennan S, Gilbert RE, Logan S
}

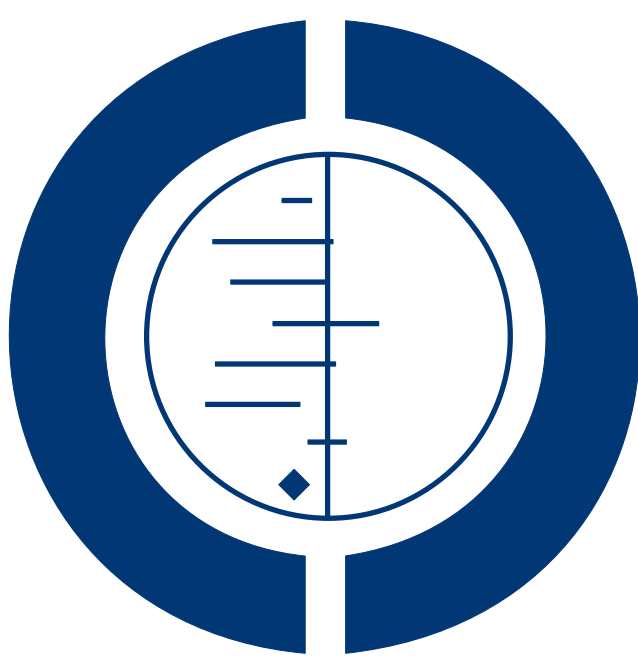

\section{THE COCHRANE COLLABORATION $^{\circledR}$}

This is a reprint of a Cochrane review, prepared and maintained by The Cochrane Collaboration and published in The Cochrane Library 2003, Issue 4

http://www.thecochranelibrary.com

\section{WILEY}


TABLE OF CONTENTS

HEADER . . . . . . . . . . . . . . . . . . . . . . . . . . . . . . . . . . . . . . . . 1

ABSTRACT . . . . . . . . . . . . . . . . . . . . . . . . . . . . . . . . . . . . . . . . . . . . . . . . . . 1

PLAIN LANGUAGE SUMMARY . . . . . . . . . . . . . . . . . . . . . . . . . . . . . . . . . . . .

BACKGROUND . . . . . . . . . . . . . . . . . . . . . . . . . . . . . . . . . . . . . .

OBJECTIVES . . . . . . . . . . . . . . . . . . . . . . . . . . . . . . . . . . . . . . . . . . . . .

METHODS . . . . . . . . . . . . . . . . . . . . . . . . . . . . . . . . . . . . . .

RESULTS . . . . . . . . . . . . . . . . . . . . . . . . . . . . . . . . . . . . . . 5

DISCUSSION . . . . . . . . . . . . . . . . . . . . . . . . . . . . . . . . . . . . . 6

AUTHORS' CONCLUSIONS . . . . . . . . . . . . . . . . . . . . . . . . . . . . . . . . . . . . . . . . .

ACKNOWLEDGEMENTS . . . . . . . . . . . . . . . . . . . . . . . . . . . . . . . . . 7

REFERENCES . . . . . . . . . . . . . . . . . . . . . . . . . . . . . . . . . . . . . . . 8

CHARACTERISTICS OF STUDIES . . . . . . . . . . . . . . . . . . . . . . . . . . . . . . . . . . . . . . . .

DATA AND ANALYSES . . . . . . . . . . . . . . . . . . . . . . . . . . . . . . . . . . . . . . . . . . . . . . . . .

Analysis 1.1. Comparison 1 Main analysis for Cisapride vs placebo, Outcome 1 'Worse, same or slight improvement' vs 'moderate or excellent improvement'. . . . . . . . . . . . . . . . . . . . . . . . . . . 19

Analysis 1.2. Comparison 1 Main analysis for Cisapride vs placebo, Outcome 2 Reflux index. . . . . . . . . . 20

Analysis 1.3. Comparison 1 Main analysis for Cisapride vs placebo, Outcome 3 Adverse events. . . . . . . . . . 21

Analysis 2.1. Comparison 2 Main analysis for Cisapride vs Gaviscon/Carobel, Outcome 1 'Worse, same or slight

improvement' vs 'moderate or excellent improvement'. . . . . . . . . . . . . . . . . . . . . . . . . . . . . . 21

Analysis 3.1. Comparison 3 Sensitivity analyses for Cisapride vs placebo, Outcome 1 Best case scenario. . . . . . . 22

Analysis 3.2. Comparison 3 Sensitivity analyses for Cisapride vs placebo, Outcome 2 Worst case scenario. $\quad . \quad$. $\quad . \quad 23$

Analysis 3.3. Comparison 3 Sensitivity analyses for Cisapride vs placebo, Outcome 3 Change in outcome definition: 'any symptoms' vs 'no symptoms' at end of treatment. . . . . . . . . . . . . . . . . . . . . . . 24

WHAT'S NEW . . . . . . . . . . . . . . . . . . . . . . . . . . . . . . . . . . . . . . 24

HISTORY . . . . . . . . . . . . . . . . . . . . . . . . . . . . . . . . . . . . . . . 24

CONTRIBUTIONS OF AUTHORS . . . . . . . . . . . . . . . . . . . . . . . . . . . . . . . . . . . . . .

DECLARATIONS OF INTEREST . . . . . . . . . . . . . . . . . . . . . . . . . . . . . . . . . . . . .

SOURCES OF SUPPORT . . . . . . . . . . . . . . . . . . . . . . . . . . . . . . . . . . . . . 25

NOTES . . . . . . . . . . . . . . . . . . . . . . . . . . . . . . . . . . . . . . . . . 25

INDEX TERMS . . . . . . . . . . . . . . . . . . . . . . . . . . . . . . . . . . . . 25

Cisapride treatment for gastro-oesophageal reflux in children (Review)

Copyright $\odot 2009$ The Cochrane Collaboration. Published by John Wiley \& Sons, Ltd. 


\title{
[Intervention Review]
}

\section{Cisapride treatment for gastro-oesophageal reflux in children}

\author{
Cristina Augood ${ }^{1}$, Suzanna MacLennan ${ }^{2}$, Ruth E Gilbert ${ }^{3}$, Stuart Logan ${ }^{4}$ \\ ${ }^{1}$ Department of Epidemiology \& Population Sciences, London School of Hygiene and Tropical Medicine, London, UK. ${ }^{2}$ Department \\ of Obstretrics and Gynaecology, University of Adelaide, Women's and Children's Hospital, Adelaide, Australia. ${ }^{3}$ Centre for Paediatric \\ Epidemiology and Biostatistics, Institute of Child Health, London, UK. ${ }^{4}$ Institute of Health and Social Care Research, Peninsula \\ Medical School, Universities of Exeter \& Plymouth, Exeter, UK \\ Contact address: Cristina Augood, Department of Epidemiology \& Population Sciences, London School of Hygiene and Tropical \\ Medicine, EUREYE Study, Epidemiology Unit, Keppel Street, London, WC1E 7HT, UK. Cristina.Augood@1shtm.ac.uk.
}

Editorial group: Cochrane Upper Gastrointestinal and Pancreatic Diseases Group.

Publication status and date: Edited (no change to conclusions), published in Issue 1, 2009.

Review content assessed as up-to-date: 12 June 2006.

Citation: Augood C, MacLennan S, Gilbert RE, Logan S. Cisapride treatment for gastro-oesophageal reflux in children. Cochrane Database of Systematic Reviews 2003, Issue 4. Art. No.: CD002300. DOI: 10.1002/14651858.CD002300.

Copyright (C) 2009 The Cochrane Collaboration. Published by John Wiley \& Sons, Ltd.

\begin{abstract}
A B S T R A C T
Background

Gastro-oesophageal reflux (GOR) is an extremely common and usually self-limiting condition in infants. When treatment is required, Cisapride, a pro-kinetic agent, has been commonly prescribed for the symptomatic management of GOR. There have been recent reports of possibly serious adverse events, e.g. an increased QTc interval, cardiac arrhythmias, and death, associated with the use of Cisapride.
\end{abstract}

\section{Objectives}

To determine the effectiveness of Cisapride for symptoms of GOR compared with placebo or any other non-surgical treatments.

\section{Search strategy}

Searches were conducted of the Cochrane Central Trials Register and the specialised Trials register of the Cochrane Upper Gastrointestinal and Pancreatic Diseases Group, MEDLINE and Embase up till April 2002. Reference lists of relevant review articles and identified trials were scrutinised and forward citation searches were performed in the Science Citation Index on all trials identified. The searches were re-run in August 2003, May 2004, June 2005 and June 2006 and no new trials were found.

\section{Selection criteria}

Randomised controlled trials that compared oral Cisapride therapy with placebo or with other non-surgical treatments for children with a diagnosis of GOR were included. Only studies in which Cisapride was administered orally for a minimum of one week and which documented at least one of the primary outcomes were included. We excluded trials in which the majority of participants were aged less than 28 days.

\section{Data collection and analysis}

The primary outcomes were defined as a change in symptoms at the end of treatment, presence of adverse events, occurrence of clinical complications, and weight gain. The secondary outcomes included physiological measures of GOR or histological evidence of oesophagitis. We dichotomised symptoms into 'same or worse' vs 'improved' and calculated summary odds ratios. Continuous measures of GOR (e.g. reflux index) were summarised as a weighted mean difference. All outcomes were analysed using a random effects method. 


\section{Main results}

Searches identified nine trials which met the inclusion criteria. Eight trials compared Cisapride with placebo, of which seven (236 participants) reported data on symptoms of gastro-oesophageal reflux, and one reported data on the QTc interval (49 patients). The odds ratio for 'same or worse' vs 'improved symptoms' at the end of treatment of 0.34 (95\%CI $0.10,1.19)$ did not show a statistically significant difference between the two interventions. There was significant heterogeneity between the studies and the funnel plot suggested publication bias. In a sensitivity analysis, the definition of outcomes was changed to 'any symptoms' vs 'no symptoms'. This resulted in the exclusion of three trials (one of them the largest, best quality trial). The resulting pooled odds ratio showed a significant effect of Cisapride (OR 0.19, 95\%CI 0.08, 0.44). Five studies reported adverse events. Four reported adverse events (mainly diarrhoea) but the difference was not statistically significant (OR 1.80, 95\%CI 0.87, 3.70). One trial found no difference in the QTc after 3 to 8 weeks of treatment. Cisapride was associated with a statistically significant reduction in the reflux index (weighted mean difference $-6.49,95 \% \mathrm{CI}-10.13,-2.85)$, but as reflux index and clinical symptoms are poorly correlated, the clinical importance of this finding is uncertain. Other measures of oesophageal $\mathrm{pH}$ monitoring did not reach significance. One included study compared Cisapride with Gaviscon (or Gaviscon and Carobel). The odds ratio for 'same or worse' vs 'improvement' in the Cisapride group compared with Gaviscon was 3.26 (95\%CI 0.93-11.38).

\section{Authors' conclusions}

We found no clear evidence that Cisapride reduces symptoms of GOR. The results suggested substantial publication bias favouring studies showing a positive effect of Cisapride. This finding is supported by the report of one unpublished multi-centre study of 134 patients, which was reported to show no evidence of a significant effect of Cisapride. Due to reports of fatal cardiac arrhythmias or sudden death, from July 2000, cisapride was restricted to a limited access programme supervised by a paediatric gastrologist in the USA and in Europe, to patients treated within a clinical trial or safety study or registry programme.

\section{PLAIN LANGUAGESUMMARY}

\section{Cisapride treatment for gastro-oesophageal reflux in children}

We found no clear evidence that Cisapride reduces symptoms of Gastro-oesophageal reflux (GOR). Due to reports of fatal cardiac arrhythmias or sudden death, from July 2000, cisapride was restricted to a limited access programme supervised by a paediatric gastrologist in the USA and in Europe, to patients treated within a clinical trial or safety study or registry programme.

\section{B A C K G ROU N D}

Gastro-oesophageal reflux (GOR), or the passage of gastric contents into the oesophagus, has a multifactorial pathophysiology. Regurgitation of stomach contents into the oesophagus is normally prevented by the action of the lower oesophageal sphincter (LES). Two different mechanisms contribute to LES tone: the skeletal muscle of the diaphragm which surrounds the oesophagus as it passes through the diaphragm, and the smooth muscle at the gastro-oesophageal junction. Low basal oesophageal sphincter pressure and transient relaxation of the LES, oesophageal dysmotility resulting in impaired clearance, and delayed emptying of the stomach and duodenum can all contribute to GOR.

In most infants with GOR the outcome is benign. The determining factor in seeking medical assistance may be parental anxiety or intolerance of symptoms rather than the presence of significant complications. In a small minority, GOR is associated with significant problems such as respiratory sequelae (chronic cough, wheezing, apnoea, hoarseness, stridor, recurrent bronchitis, pneumonia), neuro-behavioural manifestations (back-arching, feeding refusal, rumination, non-specific irritability, sleep disturbance), oesophagitis, oesophageal strictures, and failure to thrive. The term gastro-oesophageal reflux disease (GORD) describes the association of definite pathology, in most cases oesophagitis, with reflux.

Infantile gastro-oesophageal reflux has a peak incidence around 4 months and resolves spontaneously by 1 to 2 years of age in most patients (Rudolph 1996; Nelson 1997). A much smaller number of children have symptoms of GOR later in childhood; only some of these children will have had GOR in infancy. Less than $50 \%$ of 
children who develop reflux after the age of 3 have spontaneous resolution of symptoms (Treem 1991). A substantial proportion of these children will have other problems, including neurological or chronic respiratory disease.

A diagnosis of GOR is usually made on clinical grounds. Treatment for GOR, when this is deemed necessary, can be started before performing expensive and often unnecessary investigations (the Working Group of the European Society of Paediatric Gastro-Enterology and Nutrition (ESPGAN) on Gastro-Oesophageal Reflux, in Vandenplas 1993). Though not always essential for diagnosis, there are a number of investigations available to assess the cause and quantity of the reflux and to detect the presence of reflux-related complications: extended (18-24 hour) oesophageal $\mathrm{pH}$ monitoring, upper gastro-intestinal endoscopy, oesophageal manometry, scintigraphy, or sonography. These have low sensitivities and specificities and do not allow correlation of the reflux episodes with the patient's symptoms. Moreover, these investigations are generally poor predictors of how children will respond to treatment (Cucchiara 1996). A few variables, e.g. sleep reflux, acid clearing time, percentage time $\mathrm{pH}<4$, oesophageal motility parameters, may predict which children are likely to have continuing problems despite medical treatment (Colson 1990; Cucchiara 1996, Varty 1993).

There are four main types of therapy in infants with GOR: surgery, drugs, dietary measures (thickened feeds, frequent small meals) and positioning (avoidance of slumped seated or supine postures). Surgical treatment is usually reserved for complicated cases, while most are treated with some combination of the other options. Pharmacological therapies include acid-secretion inhibitors (e.g. cimetidine, ranitidine, omeprazole, lansoprazole) with or without prokinetic agents (e.g. cisapride, bethanechol, metoclopramide), when oesophagitis is present.

Cisapride is administered orally 15-30 minutes before a meal to ensure maximum plasma levels immediately after food intake. It is a gastrointestinal prokinetic agent which stimulates lower oesophageal, gastric, small intestinal and colonic motility, acting probably by enhancing the release of acetylcholine at the level of the myenteric plexus in the gut wall.

Although cisapride has never been licensed for children under 12 years it has been prescribed to over 36 million children worldwide (Vandenplas 1999), including 19\% of preterm newborns in Canadian neonatal units (Ward 1999). In 1999, a consensus statement by the European Society of Paediatric Gastroenterology, Hepatology and Nutrition (Vandenplas 1999) recommended cisapride as the drug of first choice stating that "the potential benefits far outweigh the potential risks and provide strong justification for its continued use." Since 1993 there have been 175 reports worldwide of fatal cardiac arrhythmia or sudden death associated with cisapride use, at least two deaths in children, and 261 non-fatal but serious ventricular arrhythmias
(Klausner 1998). These adverse events led to the withdrawal of cisapride from the UK and USA markets in July 2000 (Henney 2000; Breckenridge 2000). To-date, the effectiveness of cisapride for the treatment of reflux in children has not been systematically evaluated. As cisapride continues to be used, albeit within restricted programmes in the USA (http://www.fda.gov/medwatch/ safety/2000/propul1.htm accessed 29.04.02) and Europe (http: //www.emea.eu.int/pdfs/human/press/pr/392601en.pdf accessed 29.04.02) (Henney 2000), information on its effectiveness is required to enable clinicians and policy makers decide whether the low risk of serious adverse events is outweighed by the benefits of treatment.

\section{O B JE C T I VES}

The objective of this review was to compare the effectiveness of Cisapride in reducing the symptoms of gastro-oesophageal reflux with:

\section{1. placebo}

2. other medical treatments

3. dietary interventions

4. positioning

5. any combination of other treatments

\section{METHODS}

\section{Criteria for considering studies for this review}

\section{Types of studies}

Searches were carried out for randomised controlled trials comparing oral cisapride therapy with placebo or with other non-surgical treatments (other prokinetic drugs, with or without acid-secretion inhibitors, dietary measures, positioning), in children with gastrooesophageal reflux. Searches for unpublished data are ongoing.

\section{Types of participants}

Children (less than 18 years) with a diagnosis of gastro-oesophageal reflux, however defined. We excluded trials in which the majority of participants were aged less than 28 days. This is because cisapride is prescribed to neonates for feed intolerance. This is a different clinical entity from gastro-oesophageal reflux, may be due to different physiological mechanisms, and may respond differently to cisapride than does GORD in older children (Enriquez 1998). 


\section{Types of interventions}

1. Cisapride vs. placebo

2. Cisapride vs. other medical therapies (bethanechol, metoclopramide, cimetidine, ranitidine, omeprazole, lansoprazole, Gaviscon)

3. Cisapride vs. dietary interventions (small meals, thickened infant feedings)

4. Cisapride vs. positioning (avoidance of slumped seated or supine postures)

5. Cisapride vs. any combination of other non-surgical therapies Because of the restriction of surgical treatment to complicated cases of GOR we did not expect to find randomised controlled trials in this area and they were not sought.

We looked for studies in which Cisapride was administered orally for a minimum of one week.

\section{Types of outcome measures}

Cisapride treatment usually precedes physiological investigations for GOR and primarily aims to improve symptoms and avoid serious complications of GOR.

Primary outcomes:

* Symptoms, or change in symptoms, of gastro-oesophageal reflux (regurgitation, crying, irritability, vomiting, gagging) assessed subjectively by the parent/guardian of child and/or by the treating physician

* Presence of any of the following adverse events: abdominal pain, borborygmi, diarrhoea, headaches, hypersensitivity, convulsions, extrapyramidal effects, increased urinary frequency, liver function abnormalities, increased QTc interval on ECG

* Occurrence of any clinical complications of GOR, e.g. respiratory symptoms

* Weight gain

Secondary outcomes:

* Episodes of reflux measured by extended oesophageal $\mathrm{pH}$ monitoring: percentage of time during which $\mathrm{pH}<4$ ("reflux index"), number of episodes of $\mathrm{pH}<4$, number of episodes of $\mathrm{pH}<4$ lasting $>5$ minutes, duration of longest episode of $\mathrm{pH}<4$

* LES pressure measured by oesophageal manometry

* Histological evidence of oesophagitis on biopsy

Included studies had to report at least one of the primary outcomes.

\section{Search methods for identification of studies}

See: Collaborative Review Group search strategy

Searches were conducted of the Cochrane Central Trials Register (CCTR) and the specialised trials register of the Cochrane Upper Gastrointestinal and Pancreatic Diseases Group (see Review Group details for more information) using terms related to gastrooesophageal reflux and Cisapride.

In addition, the reviewers searched the MEDLINE and EMBASE electronic databases. The search strategy included appro- priate $\mathrm{MeSH}$ terms and text terms including: cisapride, gastrooesophageal reflux, idiopathic gastro-oesophageal reflux, uncomplicated gastro-oesophageal reflux, gastro-oesophageal reflux disease, infantile reflux, regurgitation, excessive regurgitation, with appropriate truncations and misspellings. These were combined with the use of the most sensitive Cochrane trials filters. Reference lists of relevant review articles and identified trials were scrutinised and forward citation searches were performed in the Science Citation Index on all trials identified. The drug manufacturers were contacted for any unpublished trials.

Searches were updated on 5 April 2002 using the above strategy on pre-MEDLINE, EMBASE and the Cochrane Library. An adapted strategy was used for Pub-Med. The pharmaceutical company Janssen was contacted for unpublished trials. The searches were re-run in August 2003, May 2004, June 2005 and June 2006 and no new trials were found.

\section{Data collection and analysis}

Titles and abstracts of all studies identified by the electronic searches were reviewed on screen independently by two reviewers (CA, SM). All potentially eligible studies were retrieved in hard copy and were independently reviewed by two researchers (CA, $\mathrm{SM}$ ) against the inclusion criteria. Disagreements were resolved by consensus with provision for arbitration by a third reviewer if required (RG or SL). Additional information was sought for one included trial (Cohen 1999). The reasons for exclusion of trials are given in the table of 'Characteristics of Excluded Studies'.

The methodological quality of the included trials was assessed independently by two reviewers (CA, SM) using a checklist developed for this purpose. For each included trial, information was collected regarding the method of randomisation, allocation concealment, blinding of outcome assessment, and the relevant interventions and outcomes. Data were extracted independently by two reviewers (CA, SM) and any discrepancies were discussed and resolved. Data were then entered into the Review Manager software by one reviewer (CA) and accuracy was checked by two other reviewers (SM, RG).

We preferentially included symptoms assessed by parents as they are likely to have greater contact with their child and therefore have a more accurate view of the change in symptoms. However, where parental assessments were not available, we included physician measures of symptoms, as we considered that they were assessing the same entity.

Studies reported symptoms or change in symptoms at the end of the treatment period in a variety of ways. An a priori decision was made to dichotomise data as 'same or worse' vs 'improvement' and in a sensitivity analysis to examine the effect of redefining the outcomes as 'any symptoms' vs 'no symptoms'. Decisions about how best to dichotomise the data were reached by two reviewers (RG, $\mathrm{SL}$ ) without knowledge of the results. Changes in oesophageal $\mathrm{pH}$ measurements at the end of treatment were considered to be a sec- 
ondary outcome as $\mathrm{pH}$ measurements are not reliable (Hampton 1990) and correlate poorly with symptoms and response to treatment (Cucchiara 1996). We were able to analyse results for the reflux index (percentage of $24 \mathrm{~h}$ with oesophageal $\mathrm{pH}<4$ ) as this is the most common measure reported.

For dichotomous data, a random effects meta-analysis was performed to determine a summary odds ratio. Where continuous data outcomes were measured in a standard way across studies (e.g. reflux index), the pooled weighted mean difference was calculated, again using a random effects model. The denominators for these calculations were all children for whom outcome data had been reported. Analysis was by intention to treat. Sensitivity analyses involved re-calculation of the summary OR for trials with good allocation concealment. For the primary outcome of'same or worse' symptoms, we analysed funnel plot asymmetry, and hence the likelihood of bias, using the regression method as described by Egger et al (Egger 1997). Evidence of heterogeneity was sought using a standard chi square statistic.

Planned subgroup analyses in children under and over one year old, in those with uncomplicated and complicated gastro-oesophageal reflux, those with neurological impairment, and in trials where the assessment of outcomes was blinded vs those in which it was non-blinded were not conducted as appropriate trials were not identified.

\section{RE S U L T S}

\section{Description of studies}

See: Characteristics of included studies; Characteristics of excluded studies; Characteristics of ongoing studies.

Nine trials met the inclusion criteria (see table of 'Characteristics of Included Studies'). Eight of these compared the effects of Cisapride with placebo (Cohen 1999; Cucchiara 1987; Escobar Castro 1994; Levy 2001; Scott 1997; Van Eygen 1989(a) \& Van Eygen 1989(b); Vandenplas 1991). In two studies (Scott 1997; Vandenplas 1991) positioning and/or thickened feeds were also given in both experimental and control arms. One paper (Van Eygen 1989(a) + b) presented data from three trials. Two of these, on different patient populations, met our inclusion criteria; they were used separately and are identified accordingly. In one trial (Greally 1992) Cisapride was compared with Gaviscon with or without Carobel. Preliminary results reported from an on-going study of symptomatic children over 2 months old with biopsyproven oesophagitis were published in abstract form (Orenstein 2000, see "Characteristics of ongoing studies"). Unpublished data are currently being sought.

Studies reported a change in symptoms following the intervention, with some exceptions: the Escobar Castro 1994 study reported symptoms at the end of the treatment period, and in the study by Cucchiara 1987 improvement in symptoms alone could not be separated from improvement in the $\mathrm{pH}$ probe results and histopathological changes. Both these studies were included, however, and their contribution to the overall results was explored in a sensitivity analysis.

The study by Levy 2001 only reported data on the QTc interval of the ECG. These data were from a seven centre double blind, placebo controlled study of 134 children on the safety and efficacy of cisapride conducted from 1991-94 with the support of Janssen Pharmaceutical Inc. Levy et al state that "because efficacy results did not reach statistical significance (possibly because inclusion criteria were too broadly defined), they were not published". The response to a request to Janssen-Cilag Ltd UK for unpublished data was that they were not aware of any unpublished data. Further information is being sought.

The children included in the trials were aged between 5 days and 5 years. They had a diagnosis of GOR defined by clinical symptoms alone or with additional oesophageal $\mathrm{pH}$ monitoring. Children were generally excluded from the trials if they required concomitant therapy with drugs interfering with assessment of the study drug, had reflux caused by known anatomic abnormalities, underlying disease, or infection of the GI tract or other organ system, or had neurologic, metabolic, or renal disorders (see table of 'Characteristics of Included Studies').

The dosage used was $0.8 \mathrm{mg} / \mathrm{kg} /$ day, with three exceptions: in one study (Cucchiara 1987) $0.9 \mathrm{mg} / \mathrm{kg} /$ day was used, in another (Van Eygen 1989 (a)) $0.45 \mathrm{mg} / \mathrm{kg} / \mathrm{day}$, and in another study (Levy 2001) $0.6 \mathrm{mg} / \mathrm{kg} /$ day. The duration of the trials ranged between 2 and 8 weeks. In five of the eight trials included, Cisapride had been supplied by the manufacturing company (Cohen 1999; Greally 1992; Scott 1997; Van Eygen 1989(a); Van Eygen 1989(b)).

Eight studies identified by the search strategy were excluded: in two (Cucchiara 1990; Saye 1987) Cisapride had been given for less than 24 hours; in three (Barnett 2001; Pezzati 2001; McClure 1999) Cisapride was administered to preterm infants with feed intolerance; in two studies Cisapride was administered to preterm infants prophylactically for feed intolerance (Enriquez 1998; Reddy 2000); and two studies did not report any of the outcomes required for inclusion in the review (Heine 1996; McClure 1999).

\section{Risk of bias in included studies}

Two trials reported adequate allocation concealment (Cohen 1999; Scott 1997). In the remaining seven the method for allocation concealment is unclear. In one study (Greally 1992) a doubleblind design was not feasible, due to the different mode of preparation and time of administration of Cisapride and Gaviscon with or without Carobel. The remaining eight trials stated that they were double blind but did not provide further details.

In only one case all of the infants randomized completed the study (Greally 1992). Losses to follow up in the other studies varied 
from as little as one and three (Escobar Castro 1994; Cucchiara 1987 ) to as much as $30 \%$ of the randomized population in three studies (Cohen 1999; Levy 2001; Vandenplas 1991). In the study by Cucchiara 1987 the total number of patients included was reported, as was the number of patients in each group who completed the trial, but not the number randomized to the treatment and control arms. For this study, we made the assumption that randomization had produced equal numbers in each group.

\section{Effects of interventions}

\section{CISAPRIDE VS PLACEBO}

Seven trials, including 236 participants, compared symptoms of GOR after treatment with Cisapride or with placebo. Our analysis of symptoms is based on parental evaluation in four trials (Cohen 1999; Escobar Castro 1994; Scott 1997; Vandenplas 1991) and physician assessment in the remaining three trials. The pooled odds ratio (random effects model) for Cisapride vs placebo for 'same or worse' vs 'improvement' was 0.34 (95\%CI 0.10, 1.19). The odds ratio after exclusion of the study by Escobar Castro 1994 (OR 0.59, 95\%CI 0.22, 1.59) or the study by Cucchiara 1987 (OR 0.41, 95\%CI 0.11, 1.54) did not change appreciably. Analysis of the effects of Cisapride after redefining outcomes as 'any symptoms' vs 'no symptoms' was restricted to five trials (a total of 156 participants) (Cucchiara 1987; Escobar Castro 1994; Scott 1997; Van Eygen 1989(a); Van Eygen 1989(b); Vandenplas 1991). The pooled odds ratio (random effects) for Cisparide versus placebo for 'any symptoms' vs 'no symptoms' was 0.19 (95\% CI $0.08,0.44)$.

The analysis of symptoms showed significant heterogeneity (chi square $=24.23 ; \mathrm{df}=6 ; \mathrm{p}<0.0001$ for 'same or worse' vs 'improvement'; chi square $=3.69, \mathrm{df}=4, \mathrm{p}=0.0002$ for 'any symptoms' vs 'no symptoms'). The reasons for the heterogeneity are not obvious from examination of the included trials which were conducted in clinically similar populations and report similar baseline event rates. The funnel plot was asymmetrical, suggesting an absence of small studies showing small or no benefit of Cisapride. The intercept with this method was -5.07 (95\%CI: -7.18 to -2.95$)$. This result is consistent with publication bias favouring studies showing a positive effect of cisapride. The results regarding the benefits of cisapride should therefore be interpreted with caution.

Adverse events (principally diarrhoea) were reported in four trials (a total of 190 participants). There were fewer adverse events in the placebo than in the Cisapride group, but the difference was not statistically significant (OR for Cisapride vs placebo 1.80, 95\%CI 0.87-3.70). One trial (Levy 2001) reported data on the QTc interval following 3-8 weeks of either cisapride or placebo. No statistically significant differences were found between the two groups in either total QTc interval duration or change in QTc interval compared with baseline. Mean QTc was 408+/-21 ms in the cisapride group and $399+/-21 \mathrm{~ms}$ in the placebo group, and the change in QTc was $1.7+/-18 \mathrm{~ms}$ and $2.4+/-20 \mathrm{~ms}$, respectively.

A primary outcome for our study was weight gain following the intervention but none of the trials reported these data. For the study by Cohen 1999, the mean difference in weight gain at the end of the 2 week trial was based on data provided by the authors. The difference between the two groups was not statistically significant $(0.9 \mathrm{~kg}, 95 \% \mathrm{CI}-0.38,2.18)$.

Use of Cisapride was associated with a reduction in the reflux index, as measured by oesophageal $\mathrm{pH}$ monitoring in five studies. The weighted mean difference for Cisapride vs placebo was -6.49 (95\%CI -10.13, -2.85). Several other physiological measured were reported. The difference between the Cisapride and the placebo groups was not statistically significant for number of episodes of $\mathrm{pH}<4$ in 24 hours (data available from two studies), number of reflux episodes lasting more than 5 minutes (data from three studies), or lower oesophageal sphincter pressure (data from two studies). The duration of the longest episode of reflux was significantly reduced in the Cisapride group (data from 3 studies) (results not shown).

For this review we also looked for histological evidence of oesophagitis at biopsy. Three trials reported data. In Cohen 1999 only 6 of 68 patients underwent endoscopy and there was no difference in the presence of 'mild histologic oesophagitis' between the Cisapride and the placebo group (2/4 vs $1 / 2)$. In Cucchiara 1987 the degree of oesophagitis was histologically defined as 'mild', 'moderate' or 'severe' and transformed into a score. Cisapride was more effective than placebo but only 3 of the 17 patients included in the study had severe oesophagitis at the beginning. In Scott 1997 the biopsy was repeated at the end of the trial only if oesophagitis had been present at baseline. The difference in abnormal findings between the Cisapride and the placebo group (7/11 vs 5/9) was not statistically significant.

\section{CISAPRIDE VS OTHER MEDICAL INTERVENTIONS}

One study comparing Cisapride with Gaviscon (or Gaviscon and Carobel in 21 of 24 cases) was identified (Greally 1992). The'same or worse symptoms' were slightly more common in the cisapride than in the gaviscon group but this difference was not significant: odds ratio 3.26 (95\%CI 0.93-11.38). The outcomes in this study were based on evaluations by parents who were not blind to the intervention.

\section{I S C USSION}

We found no clear evidence for a significant effect of cisapride compared with placebo on symptoms of GOR in children. However, the midpoint estimate of the summary odds ratio was 0.34 . This result is likely to be an overestimate of the benefits of cisapride. The analysis of funnel plot asymmetry showed that the intercept from the regression analysis was -5.07. In an analysis of 75 meta-analyses published in the Cochrane Library and in four 
leading journals, Egger 1997 reported intercepts varying from 3.5 to +3.5 . In comparison, our result shows extreme asymmetry reflecting an inverse association between study precision and an apparent beneficial effect of cisapride. While this relationship may reflect real differences between large and smaller trials, it may be explained by publication bias favouring submission or publication of small positive studies rather than small negative studies. This possibility is supported by the report of a multi-centre trial of 134 children randomized to either cisapride or placebo (with or without cimetidine) which were not published "because efficacy results did not reach statistical significance (possibly because inclusion criteria were too broadly defined)" (Levy 2001). The four smallest studies in this review had unclear allocation concealment, which has been reported to be associated with an overestimate of treatment effect (Schulz 1995). If the analysis was restricted to the two trials with good allocation concealment, the summary odds ratio was $1.94(0.87,4.31)$.

There was substantial heterogeneity of results between trials. The source of this heterogeneity is unclear as there was no obvious clinical heterogeneity (age, method of GOR diagnosis, dose and length of interventions were broadly similar).

We found a statistically significant reduction in the reflux index with Cisapride compared to placebo. The reflux index is generally taken to be the percentage time $\mathrm{pH}<4$ at 24 hour $\mathrm{pH}$ monitoring and the reduction suggested by this analysis was equivalent to 1.5 hours (with $95 \% \mathrm{CI}$ of 40 minutes to almost 2.5 hours). This finding however has to be seen in the context of a lack of correlation between the reflux index and clinical symptoms and the evidence of publication bias.

Only one small study was found which compared the use of Cisapride with Gaviscon or a combination of Gaviscon and Carobel and the results did not reach conventional levels of statistical significance. No studies were identified comparing Cisapride with other forms of treatment.

This review did not find a statistically significant difference in adverse events between Cisapride and placebo. However, serious adverse events are rare and are unlikely to be detected by small trials. Recent reports from surveillance studies of death and life threatening events potentially related to Cisapride, together with the uncertain benefits of Cisapride, have led to the decision to stop marketing Cisapride in the United States (Henney 2000).

\section{A U T HOR S' CONCLUSIONS}

\section{Implications for practice}

Our findings of a lack of evidence for a beneficial effect of cisapride contradict widely held opinions to the contrary (Vandenplas 1999; Shulman 2000 ). This review found no statistically significant effect of cisapride on symptoms of GOR, although the results were consistent with a substantial reduction, no effect, or even an increase in symptoms associated with cisapride treatment compared with placebo. Only one study was found which compared cisapride with another treatment and its results do not show cisapride to be more effective than Gaviscon with or without Carobel in the treatment of GOR in children. In this review there was evidence of substantial funnel plot asymmetry which may be explained by publication bias. There was also statistical heterogeneity between the trials which may be related to variation in study quality. For these reasons, the results are uncertain and should be interpreted with caution. Finally, this review has highlighted the paucity of randomised controlled trial information for such a widely prescribed drug. However, due to the potential for serious adverse events, large randomised trials of Cisapride with long term followup are unlikely to be conducted.

\section{Implications for research}

The literature search did not find sufficient trials to fulfil all the objectives of this review. Due to the restricted use of Cisapride since July 2000, a larger study to determine the effectiveness of Cisapride for GOR in children is no longer possible.

\section{ACKNOWLEDGEMENTS}

We thank Professor Geoffrey P Davidson for providing additional information for one study trial; Dr Billy Bourke, Professor B Drumm and Dr Jaqui Dalby-Payne for their comments on the first draft of the original review, Susan Orenstein for her comments on a subsequent version and Melissa Harden for assisting in the search for unpublished trials from the pharmaceutical company Janssen. 


\section{R E F E R E N C E S}

\section{References to studies included in this review}

Cohen 1999 \{published and unpublished data\}

Cohen RC, O'Loughlin EV, Davidson GP, Moore DJ, Lawrence DM. Cisapride in the control of symptoms in infants with gastroesophageal reflux. A randomized, doubleblind, placebo-controlled trial. J Pediatr 1999;134:287-92.

Cucchiara 1987 \{published data only\} Cucchiara S, Staiano A, Capozzi C, Di Lorenzo C, Boccieri A, Auricchio S. Cisapride for gastro-oesophageal reflux and peptic oesophagitis. Arch Dis Child 1987;62:454-457.

Escobar Castro 1994 \{published data only\}

Escobar Castro H, Bettas Ferrero G, Suarez Cortina L, Camarero Salces C, Lima M. [Efectividad del Cisapride en el tratamiento del reflujo gastroesofagico (R.G.E.) en ninos. valoracion de un estudio a doble ciego]. An Esp Pediatr 1994;40(1):5-8.

Greally 1992 \{published data only\} Greally P, Hampton FJ, MacFadyen UM, Simpson H. Gaviscon and Carobel compared with cisapride in gastrooesophageal reflux. Arch Dis Child 1992;67:618-621.

Levy 2001 \{published data only\}

Levy J, Hayes C, Kern J, Harris J, Flores A, Hyams J, Murray R, Tolia V. Does cisapride influence cardiac rhythm? Results of a United States multicenter, doubleblind, placebo-contolled pediatric study. Journal of Pediatric Gastroenterology and Nutrition 2001;32:458-463.

Scott 1997 \{published data only\}

Scott RB, Ferreira C, Smith L, Jones AB, Machida $\mathrm{H}$, Lohoues MJ, Roy CC. Cisapride in pediatric gastroesophageal reflux. J Ped Gastroenterol Nutr 1997;25: 499-506.

Van Eygen 1989(a) \{published data only\}

Van Eygen M, Van Ravensteyn H. Effect of cisapride on excessive regurgitation in infants. Clin Ther 1989;11(5): 669-677.

Van Eygen 1989(b) \{published data only\}

Van Eygen M, Van Ravensteyn H. Effect of cisapride on excessive regurgitation in infants. Clin Ther 1989;11(5): 669-677.

Vandenplas 1991 \{published data only\}

Vandenplas Y, De Roy C, Sacre L. Cisapride decreases prolonged episodes of reflux in infants. J Ped Gastroenterol Nutr 1991;12:44-47.

\section{References to studies excluded from this review}

Barnett 2001 \{published data only\}

Barnett CP, Omari T, Davidson GP, Goodchild L, Lontis R, Dent J, Haslam RR. Effect of cisapride on gastric emptying in premature infants with feed intolerance. J Paediatr Child Health 2001;37:559-563.

Cucchiara 1990 \{published data only\}

Cucchiara S, Staiano A, Boccieri A, De Stefano M, Capozzi C, Manzi G, Camerlingo F, Paone FM. Effects of cisapride on parameters of oesophageal motility and on the prolonged intraoesophageal $\mathrm{pH}$ test in infants with gastro-oesophageal reflux disease. Gut 1990;31:21-25.

Enriquez 1998 \{published data only\}

Enriquez A, Bolisetty S, Patole S, Garvey PA, Campbell PJ. Randomised controlled trial of cisapride in feed intolerance in preterm infants. Arch Dis Child Fetal Neonatol Ed 1998; 79:F110-F113.

Heine 1996 \{published data only\}

Heine RG, Catto-Smith AG, Reddihough DS. Effect of antireflux medication on salivary drooling in children with cerebral palsy. Devel Med Child Neurol 1996;38: $1030-1036$.

McClure 1999 \{published data only\} McClure RJ, Kristensen JH, Grauaug A. Randomised controlled trial of cisapride in preterm infants. Arch Dis Child Fetal Neonatal Ed 1999;80:F174-F177.

Pezzati 2001 \{published data only\} Pezzati M, Dani C, Biadaioli R, Gambi B, Lachina L, Rubaltelli FF. Randomised controlled trial of the effect of cisapride on the pyloric muscle in preterm infants. Eur J Pediatr 2001;160:572-575.

Reddy 2000 \{published data only\}

Reddy PS, Deorari AK, Bal CS, Paul VK, Singh M. A double-blind placebo-controlled study on prophylactic use of cisapride on feed intolerance and gastric emptying in preterm neonates. Indian Pediatrics 2000;37:837-844.

Saye 1987 \{published data only\}

Saye ZN, Forget P, Geubelle F. Effect of Cisapride on gastroesophageal reflux in children with chronic bronchopulmonary disease: A double-blind cross-over $\mathrm{pH}$ monitoring study. Pediatr Pulmonol 1987;3:8-12.

\section{References to ongoing studies}

Orenstein 2000 \{published data only\} Cisapride, cimetidine, both, or neither for infantile esophagitis: symptomatic \& histologic results. Ongoing study December 1999.

\section{Additional references}

\section{Bernardini 1997}

Bernardini S, Semama DS, Huet F, Sgro C, Gouyon JB. Effects of cisapride on QTc interval in neonates. Arch Dis Child Fetal Neonatal Ed 1997;77(3):F241-3.

Breckenridge 2000

Breckenridge A. Suspension of cisapride (Prepulsid) licences: Product withdrawal. Committee on Safety of Medicines, London 2000.

Colson 1990 Colson DJ, Campbell CA, Wright VA, Watson BW. Predictive value of oesophageal $\mathrm{pH}$ variables in children with gastro-oesophageal reflux. Gut 1990;31:370-3. 


\section{Cucchiara 1996}

Cucchiara S, Campanozzi A, Greco L, Franco MT, Emiliano M, Alfieri E, Calabrese F, Numeroso V. Predictive value of esophageal manometry and gastroesophageal $\mathrm{pH}$ monitoring for responsiveness of reflux disease to medical therapy in children. American Journal of Gastroeneterology 1996;91(4):680-685.

\section{Egger 1997}

Egger M, Smith GD, Schneider M, Minder C. Bias in meta-analysis detected by a simple, graphical test. $B M J$ 1997;315:629-634.

\section{Hampton 1990}

Hampton FJ, MacFayden UM, Simpson H. Reproducibility of 24 hour oesophageal $\mathrm{pH}$ studies in infants. Archives of Diseases in Childhood 1990;65:1249-54.

\section{Henney 2000}

Henney JE. Withdrawal of troglitazone and cisapride. JAMA 2000;283:17.

\section{Hill 1998}

Hill SL, Evangelista JK, Pizzi AM, Mobassaleh M, Fulton DR, Berul CI. Proarrhythmia associated with cisapride in children. Pediatrics 1998;101(6):1053-1056.

\section{Klausner 1998}

Klausner, M. A. Jansen Pharmaceutica Research Foundation. Important safety and efficacy information. http:// pharminfo.com/medwatch/mwrpt50.html (accessed June 2000) 1998.

\section{Lewin 1996}

Lewin MB, Bryant RM, Fenrich AL, Grifka RG. Cisaprideinduced long QT interval. J Pediatr 1996;128:279-281.

\section{Lupoglazoff 1997}

Lupoglazoff JM, Bedi A, Faure C, Denjoy I, Casasoprana A, Cezard JP, Aujard Y. Long QT syndrome under cisapride in neonates and infants [Allongement de l'espace QT sous cisapride chez la nouveau-ne et le nourrisson]. Arch Pediatr 1997;4:509-14.

\section{Nelson 1997}

Nelson SP, Chen EH, Syniar GM, Kaufer Christoffel K. Prevalence of symptoms of gastroesophageal reflux during infancy. Arch Pediatr Adolesc Med 1997;151:569-572.

\section{Rudolph 1996}

Rudolph CD. Gastroesophageal Reflux. In: Rudolph AM, Hoffman JIE, Rudolph CD editor(s). Rudolph's Pediatrics. Stamford, Connecticut: Appleton and Lange, 1996: 1058-1060.

\section{Schulz 1995}

Schulz KF, Chalmers I, Hayes RJ, Altman DG. Empirical evidence of bias. Dimensions of methodological quality associated with estimates of treatment effects in controlled trials. JAMA 1995;273:408-412.

\section{Shulman 2000}

Shulman RJ, Boyle JT, Colletti RB, Friedman R, Heyman MB, Kearns G, Kirschner BS, Levy J, Mitchell AA, Van Hare G, The North American Society for Pediatrics Gastroenterology and Nutrition. An updated medical position statement of the North American Society for Pediatric Gastroenterology and Nutrition.. J Pediatr Gastroenterol Nutr 2000;31(2):232-3.

\section{Treem 1991}

Treem WR, Davis PM, Hyams JS. Gastroesophageal reflux in the older child: presentation, response to treatment and long-term follow-up. Clin Pediatr Phila 1991;30(7): 435-440.

\section{Valdes 1997}

Valdes L, Champel V, Olivier C, Jonville-Bera AP, Autret E. Syncope with long QT interval in a 39 day-old infant treated with cisapride [Malaise avec allongement de l'espace QT chez un nourrisson de 39 jours traite par cisapride]. Arch Pediatr 1997;4:535-7.

\section{Vandenplas 1993}

Vandenplas Y, Ashkenazi A, Belli D, Boige N, Bouquet J, Cadranel S, et al.A proposition for the diagnosis and treatment of gastro-oesophageal reflux disease in children: a report from a working group on gastro-oesophageal reflux disease. Eur J Pediatr 1993;152:704-711.

Vandenplas 1996 Vandenplas Y, Belli D, Benhanou PH, Cadranel S, Cezard JP, Cucchiara S, Dupont C, Faure C, Gottrand F, Hassall E, Heymans HS, Kneepkens CM, Sandhu BK. Current concepts and issues in the management of regurgitation of infants: a reappraisal.Management guidelines from a working party. Acta Paediatr 1996;85(5):531-4.

\section{Vandenplas 1999}

Vandenplas Y, Belli DC, Benatar A. The role of cisapride in the treatment of pediatric gastroesophageal reflux. $J$. Pediatr. Gastroenterol. Nutr. 1999;28:518-28.

\section{Varty 1993}

Varty K, Evans D, Kapila L. Paediatric gastr-oesophageal reflux: prognostic indicators from $\mathrm{pH}$ monitoring. Gut 1993;34:1478-1481.

\section{Ward 1999}

Ward RM, Lemons JA, Molteni RA. Cisapride: a survey of the frequency of use and adverse events in premature newborns. Pediatrics 1999;103:469-72.

\section{References to other published versions of this review}

\section{Gilbert RE et al}

Gilbert RE, Augood C, MacLennan S, Logan S. Cisapride treatment for gastro-oesophageal reflux: a systematic review of randomized controlled trials. J Paediatr Child Health 2000;36:525-9.

* Indicates the major publication for the study 


\section{CHARACTERISTICS OF STUDIES}

\section{Characteristics of included studies [ordered by study ID]}

\section{Cohen 1999}

\begin{tabular}{ll}
\hline Methods & Randomized, double-blind, placebo-controlled trial \\
\hline Participants & $\begin{array}{l}\text { Age }<36 \text { mo } \\
\text { Clinical diagnosis of GOR: frequent } \mathrm{V} \text { or } \mathrm{R} \text { often associated with feeding difficulties and/or excessive } \\
\text { crying. } \\
\text { Baseline } 24-\mathrm{h} \text { oesophageal } \mathrm{pH} \text { monitoring: } \mathrm{RI}>=5 \% \text { OR GOR score (Euler } \& \text { Byrne) }>=50 . \\
\text { Exclusion criteria: anatomic abnormality of the GI tract, previous GI surgery, treatment with anticholin- } \\
\text { ergics, theophylline, other diagnosis which could explain vomiting }\end{array}$ \\
\hline Interventions & $\begin{array}{l}2 \text { weeks of either: } \\
\text { Cisapride suspension }(1 \mathrm{mg} / \mathrm{ml}) 0.2 \mathrm{mg} / \mathrm{kg} \text { qid }\left(\mathrm{n}=50^{*}\right) \\
\text { Placebo }\left(\mathrm{n}=45^{*}\right)\end{array}$ \\
\hline
\end{tabular}

Parental evaluation at 2 weeks:
overall symptom intensity on VAS $0-10 \mathrm{~cm}(0=$ absence of symptoms, $10=$ could not be worse)
improvement (marked=complete or near complete resolution of symtoms, moderate=partial resolution,
minimal=slight improvement, unchanged, deterioration)
Evaluation during the 2 weeks of treatment:
presence of vomiting, gagging, crying (score $0-3)$.
AE: any, withdrawals due to AE.
Investigator assessessment at 2 weeks:
24-h oesophageal pH
oesophagitis at biopsy

Notes 68 patients $(38,30)$ completed the trial.

Withdrawn if: consent was withdrawn, serious $\mathrm{AE}$, further investigations necessitated a change in treatment.

A high proportion of patients had received prior treatment with: thickened feeds, positional therapy, cisapride, $\mathrm{H} 2$ antagonists, antacids, metoclopramide, other

\section{Risk of bias}

\begin{tabular}{l|ll}
\hline Item & Authors' judgement & Description \\
\hline Allocation concealment? & Yes & A - Adequate \\
\hline
\end{tabular}

Cucchiara 1987

Methods

Participants
Randomized, double-blind, placebo-controlled trial

Age 75 days -47 mo

Reflux oesophagitis in all (endoscopy and biopsy).

Diagnosis of GOR made by oesophageal $\mathrm{pH}$ ( $\mathrm{pH}<4$ for $>=20$ ") and manometry. 
Cucchiara 1987 (Continued)

Exclusion criteria: infections, neurologic, metabolic, renal disorders, abnormalities of the GI tract

\begin{tabular}{|c|c|c|}
\hline Interventions & \multicolumn{2}{|c|}{$\begin{array}{l}8 \text { weeks of either: } \\
\text { Cisapride syrup }(1 \mathrm{mg} / \mathrm{ml}) 0.3 \mathrm{mg} / \mathrm{kg} \text { tid } \\
\text { Placebo syrup }\end{array}$} \\
\hline Outcomes & \multicolumn{2}{|c|}{$\begin{array}{l}\text { Assessed at } 8 \text { weeks by investigator: } \\
24-\mathrm{h} \mathrm{pH} \\
\text { LES pressure } \\
\text { oesophagitis at biopsy } \\
\text { Improvement at end of treatment: cured (clinical, pH-metric and histological variables normalised), } \\
\text { improved (at least one of the three varaibles had improved), unchanged, worsened }\end{array}$} \\
\hline Notes & \multicolumn{2}{|c|}{$\begin{array}{l}3 \text { patients were withdrawn: } 2 \text { febrile URTI, } 1 \text { failed to take drug continuously. } \\
\text { Other outcomes measured: peristalsis amplitude, clinical score }\end{array}$} \\
\hline \multicolumn{3}{|l|}{ Risk of bias } \\
\hline Item & Authors' judgement & Description \\
\hline Allocation concealment? & Unclear & B - Unclear \\
\hline
\end{tabular}

\section{Escobar Castro 1994}

\begin{tabular}{l|l}
\hline Methods & Randomized, double-blind, placebo-controlled study \\
\hline Participants & $\begin{array}{l}\text { Age } 3 \text { mo - } 5 \text { yrs } \\
\text { V and R present. } \\
\text { GOR at oesophageal pH monitoring (RI <3.5\% considered normal). } \\
\text { No organic pathology to justify the reflux. }\end{array}$ \\
\hline Interventions & $\begin{array}{l}\text { 4 weeks of either: } \\
\text { Cisapride } 0.2 \text { mg/kg (n=15) } \\
\text { Placebo (n=15) }\end{array}$ \\
\hline Outcomes & $\begin{array}{l}\text { Assessment at } 2 \text { and } 4 \text { weeks (probably by parents) of digestive symptoms: severe (R and/or V after each } \\
\text { meal of an important part of the meal), moderate (R of a small quantity more than once a day), mild (R } \\
\text { of a very small quantity once a day or sometime during the week), absent. } \\
\text { Investigator assessment at } 4 \text { weeks: } 24-h \text { oesophageal pH, AE, complications }\end{array}$ \\
\hline Notes & $\begin{array}{l}1 \text { drop-out in the cisapride group ('lack of motivation'). } \\
\text { Other outcomes measured: radiological image, endoscopy, respiratory symptoms improvement (nil, slight, } \\
\text { good, excellent) }\end{array}$ \\
\hline
\end{tabular}

\section{Risk of bias}

Item

Authors' judgement

\section{Description}


Escobar Castro 1994 (Continued)

\begin{tabular}{|c|c|c|}
\hline Allocation concealment? & Unclear & B - Unclear \\
\hline \multicolumn{3}{|l|}{ Greally 1992} \\
\hline Methods & \multicolumn{2}{|c|}{$\begin{array}{l}\text { Randomized study. } \\
\text { Double-blind design was not feasible (see text for details) }\end{array}$} \\
\hline Participants & \multicolumn{2}{|c|}{$\begin{array}{l}\text { Age } 2-18 \text { mo } \\
\text { Chronic vomiting and GOR confirmed by } 24 \mathrm{~h} \mathrm{pH} \text { oesophageal monitoring }(\mathrm{pH}<4 \text { for }>=5 \% \text { of the } \\
\text { recording period). } \\
\text { No neurological, respiratory, metabolic, GI disease, treatment with } \mathrm{H} 2 \text { antagonists, theophylline, anti- } \\
\text { cholinergic drugs }\end{array}$} \\
\hline Interventions & \multicolumn{2}{|c|}{$\begin{array}{l}4 \text { weeks of either: } \\
\text { Cisapride p.o. } 0.2 \mathrm{mg} / \mathrm{kg} \text { qid }(\mathrm{n}=26) \\
\text { Gaviscon } 1 / 2 \text { sachet to each } 90 \mathrm{ml} \text { feed qid ( } \mathrm{n}=24,21 \text { also had Carobel) }\end{array}$} \\
\hline Outcomes & \multicolumn{2}{|c|}{$\begin{array}{l}\text { Parental evaluation at } 4 \text { weeks of improvement (improved, not improved). } \\
\text { Investigator evaluation at } 4 \text { weeks of } 24-\mathrm{h} \mathrm{pH} \text { ( } \mathrm{RE} \text { was defined as } \mathrm{pH}<4 \text { for }>=15 \text { ”) }\end{array}$} \\
\hline Notes & \multicolumn{2}{|c|}{$\begin{array}{l}\text { All } 50 \text { infants completed the study. } \\
\text { Other outcomes measured at } 4 \text { weeks: daily parental evaluation of severity of V: } 0 \text { (absent), 1(1-4 episodes/ } \\
\text { day), } 2 \text { (>4 episodes/day), leading to a final symptoms score (range } 0-1 \text { ); improvement in diary scores }\end{array}$} \\
\hline \multicolumn{3}{|l|}{ Risk of bias } \\
\hline Item & Authors' judgement & Description \\
\hline Allocation concealment? & Unclear & B - Unclear \\
\hline
\end{tabular}

Levy 2001

Methods

Randomized, double-blind, placebo-controlled study.

Participants Age 6 mo - 4 years (mean age $14.4 \mathrm{mo}$ )

Min. 3 months of symptomatic GOR with failure to respond to at least 6 weeks of non-surgical treatment other than cisapride

Interventions

3-8 weeks of either Cisapride $0.6 \mathrm{mg} / \mathrm{kg} /$ day or placebo.

Outcomes

Data on QTc retained in 4 (68 patients) of 7 study centres (134 patients in total) in the trial. 19/68 excluded as ECGs recorded after 8 weeks of treatment. Mean QTc reported at 3-8 weeks of treatment and mean difference in QTc from baseline

Notes

Data on symptoms of GOR not published "because efficacy results did not reach statistical significance" 
Levy 2001 (Continued)

Risk of bias

\begin{tabular}{|c|c|c|}
\hline Item & Authors' judgement & Description \\
\hline Allocation concealment? & Unclear & B - Unclear \\
\hline
\end{tabular}

Scott 1997

Methods

Participants

Participants

(2x)

Age 6 weeks - 2 years

Daily $\mathrm{R}$ or $\mathrm{V}$ during a 1 week baseline period

AND $>=1$ episode of GOR ( $\mathrm{pH}<4$ for $>20$ ") at $18-\mathrm{h} \mathrm{pH}$ monitoring.

Exclusion criteria: not meeting the inclusion criteria, premature, previous GI surgery (excluding for appendicitis), illnesses $\&$ drugs that could interfere with cisapride, reflux due to known anatomic abnormalities, underlying disease, infection of the GI tract, parents who couldn't express concern, comply with study, complete diaries

Interventions

6 weeks of positioning and thickened feeds (where appropriate) and either:

Cisapride suspension $(1 \mathrm{mg} / \mathrm{ml}) 0.2 \mathrm{mg} / \mathrm{kg}$ qid $(\mathrm{n}=23)$

Placebo suspension $(\mathrm{n}=26)$
Assessed at 2,4,6 weeks by parent and investigator: global evaluation of condition on VAS $0-100 \mathrm{~mm}(0=$ the worst it's ever been, $100=$ completely recovered); any AE, specific AE.

Assessed at 6 weeks by parent and investigator: global evaluation of overall treatment (deterioration= symptoms worse, poor=no improvement, fair=slight improvement, persistence of some symptoms, good= improvement, occasional symptoms, excellent=complete relief of symptoms).

Assessed at 6 weeks by investigator: 24-h pH, LES pressure, oesophagitis at biopsy

Notes

45 patients (21 Cisapride, 24 Placebo) were evaluable (4 were noncompliant or had violated protocol). Other outcomes: various at $24-\mathrm{h} \mathrm{pH}$, swallow pressure, daily diary recording of each episode (none, mild, moderate, severe), score for $\mathrm{R}$ and $\mathrm{V}$

\section{Risk of bias}

$\begin{array}{lll}\text { Item Authors' judgement } \quad \text { Description } & \end{array}$

$\begin{array}{lll}\text { Allocation concealment? Yes } & \text { A - Adequate }\end{array}$


Van Eygen 1989(a)

\begin{tabular}{|c|c|}
\hline Methods & $\begin{array}{l}\text { Three trials: } \\
\text { I open trial }(\mathrm{n}=69) \\
\text { II (Van Eygen 1989a) randomized, double-blind, placebo-controlled trial }(\mathrm{n}=23) \\
\text { III (Van Eygen 1989b) dose-response trial }(\mathrm{n}=50)\end{array}$ \\
\hline Participants & $\begin{array}{l}\text { Age } 5 \text { days }-12 \text { mo } \\
\text { Excessive } \mathrm{R} \text { or } \mathrm{V} \text { at least twice a day in all children. } \\
\text { In trial II: GOR at radiology or } \mathrm{pH} \text { monitoring in all children. } \\
\text { In trial III: GOR at radiology, endoscopy or } \mathrm{pH} \text { monitoring in } 16 \text { children. } \\
\text { Non-pharmacologic measures (e.g. positioning, food thickening) had failed to improve the reflux }\end{array}$ \\
\hline Interventions & $\begin{array}{l}4 \text { weeks of either: } \\
\text { Trial II: Cisapride oral suspension } 0.15 \mathrm{mg} / \mathrm{kg} \text { tid }(\mathrm{n}=12) \\
\text { Placebo oral suspension }(\mathrm{n}=11) \\
\text { Trial III: Cisapride } 0.1 \mathrm{mg} / \mathrm{kg} \text { tid }(\mathrm{n}=14) \text { (not used in the analysis) } \\
\text { Cisapride } 0.2 \mathrm{mg} / \mathrm{kg} \text { tid }(\mathrm{n}=14) \\
\text { Placebo tid }(\mathrm{n}=17)\end{array}$ \\
\hline Outcomes & $\begin{array}{l}\text { Assessed at } 2 \text { and } 4 \text { weeks by the investigator: } \mathrm{AE} \text {, global therapeutic result (poor=no change, fair=distinct } \\
\text { but slight improvement, good=marked reduction in } \mathrm{R} \text {, excellent=virtually complete symptomatic cure) }\end{array}$ \\
\hline Notes & $\begin{array}{l}\text { In trial III analysis based on } 45 \text { of } 50 \text { patients. There were } 4 \text { early drop-outs and } 1 \text { protocol violation and } \\
\text { a further } 10 \text { drop-outs ( } 4 \text { in the Cisapride } 0.2 \mathrm{mg} / \mathrm{kg} \text { group and } 6 \text { in the placebo group. } \\
\text { Other outcomes assessed at } 2 \text { and } 4 \text { weeks by investigator: severity of } \mathrm{R} \text { (severe=the major part of the } \\
\text { meal is } \mathrm{R} \text {, moderate=effortless } \mathrm{R} \text { of a mouthful of feeding, slight=R of rather excessive saliva only, no R); } \\
\text { frequency of R (after each meal, at least twice a day, once a day or several times a week, never) }\end{array}$ \\
\hline
\end{tabular}

\section{Risk of bias}

\begin{tabular}{|c|c|c|}
\hline Item & Authors' judgement & Description \\
\hline Allocation concealment? & Unclear & B - Unclear \\
\hline
\end{tabular}

Van Eygen 1989(b)

Methods Trial III referred to above.

Participants

Interventions

Outcomes

Notes

Risk of bias

\begin{tabular}{lll}
\hline Item Authors' judgement Description & Aut
\end{tabular}


Van Eygen 1989(b) (Continued)

\begin{tabular}{|c|c|c|}
\hline Allocation concealment? & Unclear & B - Unclear \\
\hline \multicolumn{3}{|l|}{ Vandenplas 1991} \\
\hline Methods & \multicolumn{2}{|c|}{ Randomized, double-blind, placebo-controlled trial } \\
\hline Participants & \multicolumn{2}{|c|}{$\begin{array}{l}\text { Age } 2-4 \text { mo } \\
\text { Pathological GOR of V and R for }>2 \text { weeks, }>6 \text { times/day AND abnormal oesophageal pH monitoring. } \\
\text { Exclusion criteria: reflux secondary to diseases (e.g. infections, allergy, pyloric stenosis) }\end{array}$} \\
\hline Interventions & \multicolumn{2}{|c|}{$\begin{array}{l}\text { 13-16 days of positional therapy and either: } \\
\text { Cisapride }(1 \mathrm{mg} / \mathrm{ml}) 0.2 \mathrm{mg} / \mathrm{kg} \text { qid }(\mathrm{n}=21) \\
\text { Placebo }(\mathrm{n}=21)\end{array}$} \\
\hline Outcomes & \multicolumn{2}{|c|}{$\begin{array}{l}\text { Parental evaluation of GOR severity at } 2 \text { weeks: } 0 \text { (no } \mathrm{V} \text { at all), } 1 \text { ( } 1-3 \text { episodes of } \mathrm{V} \text { or } \mathrm{R} / \text { day), } 2 \text { (4-6 } \\
\text { episodes of } \mathrm{V} \text { or } \mathrm{R} / \text { day), } 3 \text { ( }>6 \text { episodes of } \mathrm{V} \text { or } \mathrm{R} / \text { day). } \mathrm{NB} \text { : all had grade } 3 \text { at the beginning. } \\
\text { Investigator evaluation at } 2 \text { weeks: } 24-\mathrm{h} \mathrm{pH} \text {. }\end{array}$} \\
\hline Notes & \multicolumn{2}{|c|}{$\begin{array}{l}\text { None of the infants received milk-thickening products. } \\
29 \text { completed the study, } 13 \text { exclusions post-randomisation: unexpected weaning }(3,3) \text {, withdrawal of } \\
\text { permission for second } \mathrm{pH} \text { monitoring because symptoms had improved }(4,1) \text {, lack of improvement } \& \\
\text { parents refused to continue }(0,2)\end{array}$} \\
\hline \multicolumn{3}{|l|}{ Risk of bias } \\
\hline Item & Authors' judgement & Description \\
\hline Allocation concealment? & Unclear & B - Unclear \\
\hline
\end{tabular}

* Number of patients in brackets represents number randomized to respective treatment group.

$\mathrm{AE}=$ adverse events, $\mathrm{GI}=$ gastro-intestinal, $\mathrm{GOR}=$ gastro-oesophageal reflux, LES=lower oesophageal sphincter, $\mathrm{R}=$ regurgitation, $\mathrm{RE}=$ reflux episode, $\mathrm{RI}=$ reflux index (percentage of time in $24 \mathrm{~h}$ during which $\mathrm{pH}<4$ ), URTI=upper respiratory tract infection, $\mathrm{V}=$ vomiting, VAS=visual analogue scale

\section{Characteristics of excluded studies [ordered by study ID]}

\begin{tabular}{ll}
\hline Study & Reason for exclusion \\
\hline Barnett 2001 & Study participants were preterm neonates. \\
\hline
\end{tabular}

Cucchiara 1990 Cisapride given i.v. in a single dose over 5 minutes. No mention of study being randomized 
(Continued)

\begin{tabular}{ll} 
Enriquez 1998 & $\begin{array}{l}\text { Cisapride was administered prophylactically during the introduction of enteral feeding by nasogastric tube to } \\
\text { preterm infants of less than } 33 \text { weeks gestation at birth }\end{array}$ \\
\hline Heine 1996 & The outcomes reported by this study (i.e. drooling) are not relevant to the review \\
\hline McClure 1999 & $\begin{array}{l}\text { The outcomes reported in this study (i.e. half gastric emptying time, whole gastrointestinal transit time) are } \\
\text { not relevant to the review. Cisapride was prescribed for clinically diagnosed gastroesophageal reflux or poor feed } \\
\text { tolerance in very preterm infants (less than } 32 \text { weeks of gestation) }\end{array}$ \\
\hline Pezzati 2001 & $\begin{array}{l}\text { Study participants were preterm neonates less than } 34 \text { weeks gestation. Cisapride was administered for feed } \\
\text { intolerance by naso-gastric tube }\end{array}$ \\
\hline Reddy 2000 & $\begin{array}{l}\text { Preterm neonates less than } 34 \text { weeks gestation. Cisapride administered prophilactically during the introduction of } \\
\text { enteral feeding }\end{array}$ \\
\hline Saye 1987 & $\begin{array}{l}\text { All infants and children were suspected of having GOR (and only } 5 \text { of them had digestive symptoms) and Cisapride } \\
\text { treatment was given for only } 16 \text { hours }\end{array}$
\end{tabular}

\section{Characteristics of ongoing studies [ordered by study ID]}

\section{Orenstein 2000}

\begin{tabular}{ll}
\hline Trial name or title & Cisapride, cimetidine, both, or neither for infantile esophagitis: symptomatic \& histologic results \\
\hline Methods & 96 children $>2$ months old with biopsy proven oesophagitis \\
\hline Participants & $\begin{array}{l}\text { 1. cisapride } 0.2 \mathrm{mg} / \mathrm{kg} \text { qid } \& \text { placebo } \\
\text { 2. cimetidine } 10 \mathrm{mg} / \mathrm{kg} \text { qid } \& \text { placebo } \\
\text { Interventions }\end{array}$ \\
\begin{tabular}{l} 
4. placebo + placebo \\
\hline
\end{tabular}
\end{tabular}

Outcomes $\quad$ Measured at 2, 6 and 12 months. Initial findings reported for 2 months.

1.symptoms measured by parents using the Infant Gastroesophageal Reflux Questionnaire

2. vomiting

3. crying

4. biospy measuring papillay height and basal layer thickness

Starting date December 1999

Contact information SR Orenstein, Academic Hospital of Pittsburgh, USA

Cisapride vs no cisapride:
symptom questionnaire showed $86 \%$ with cisapride were well or better at 2 months compared with $70 \%$ for
no cisapride groups (if 3 lost to follow-up in cisapride groups and 8 given no cisapride were assumed to have


Orenstein 2000 (Continued)

worse symptoms). No significant improvement in vomiting (frequency or volume)

Copyright $\odot 2009$ The Cochrane Collaboration. Published by John Wiley \& Sons, Ltd. 
DATA ANDANALYSES

Comparison 1. Main analysis for Cisapride vs placebo

\begin{tabular}{lcccc} 
Outcome or subgroup title & $\begin{array}{c}\text { No. of } \\
\text { studies }\end{array}$ & $\begin{array}{c}\text { No. of } \\
\text { participants }\end{array}$ & Statistical method & Effect size \\
\hline $\begin{array}{l}\text { 1 'Worse, same or slight } \\
\quad \begin{array}{l}\text { improvement' vs 'moderate or } \\
\text { excellent improvement' }\end{array}\end{array}$ & 7 & 236 & Odds Ratio (M-H, Random, 95\% CI) & $0.34[0.10,1.19]$ \\
$\begin{array}{l}\text { 2 Reflux index } \\
\text { Adverse events }\end{array}$ & 5 & 176 & Mean Difference (IV, Random, 95\% CI) & $-6.49[-10.13,-2.85]$ \\
\hline
\end{tabular}

\section{Comparison 2. Main analysis for Cisapride vs Gaviscon/Carobel}

\begin{tabular}{lcccc} 
Outcome or subgroup title & $\begin{array}{c}\text { No. of } \\
\text { studies }\end{array}$ & $\begin{array}{c}\text { No. of } \\
\text { participants }\end{array}$ & Statistical method & Effect size \\
\hline $\begin{array}{l}1 \text { 'Worse, same or slight } \\
\text { improvement' vs 'moderate or } \\
\text { excellent improvement' }\end{array}$ & 1 & 50 & Odds Ratio (M-H, Random, 95\% CI) & $3.26[0.93,11.38]$ \\
\hline
\end{tabular}

Comparison 3. Sensitivity analyses for Cisapride vs placebo

\begin{tabular}{lcccc} 
Outcome or subgroup title & $\begin{array}{c}\text { No. of } \\
\text { studies }\end{array}$ & $\begin{array}{c}\text { No. of } \\
\text { participants }\end{array}$ & Statistical method & Effect size \\
\hline 1 Best case scenario & 7 & 290 & Odds Ratio (M-H, Random, 95\% CI) & $0.21[0.08,0.54]$ \\
2 Worst case scenario & 7 & 290 & Odds Ratio (M-H, Random, 95\% CI) & $0.70[0.18,2.65]$ \\
$\begin{array}{l}\text { 3 Change in outcome definition: } \\
\begin{array}{l}\text { 'any symptoms' vs 'no } \\
\text { symptoms' at end of treatment }\end{array}\end{array}$ & 4 & 139 & Odds Ratio (M-H, Random, 95\% CI) & $0.19[0.07,0.51]$ \\
\hline
\end{tabular}


Analysis I.I. Comparison I Main analysis for Cisapride vs placebo, Outcome I 'Worse, same or slight improvement' vs 'moderate or excellent improvement'.

Review: Cisapride treatment for gastro-oesophageal reflux in children

Comparison: I Main analysis for Cisapride vs placebo

Outcome: I 'Worse, same or slight improvement' vs 'moderate or excellent improvement'

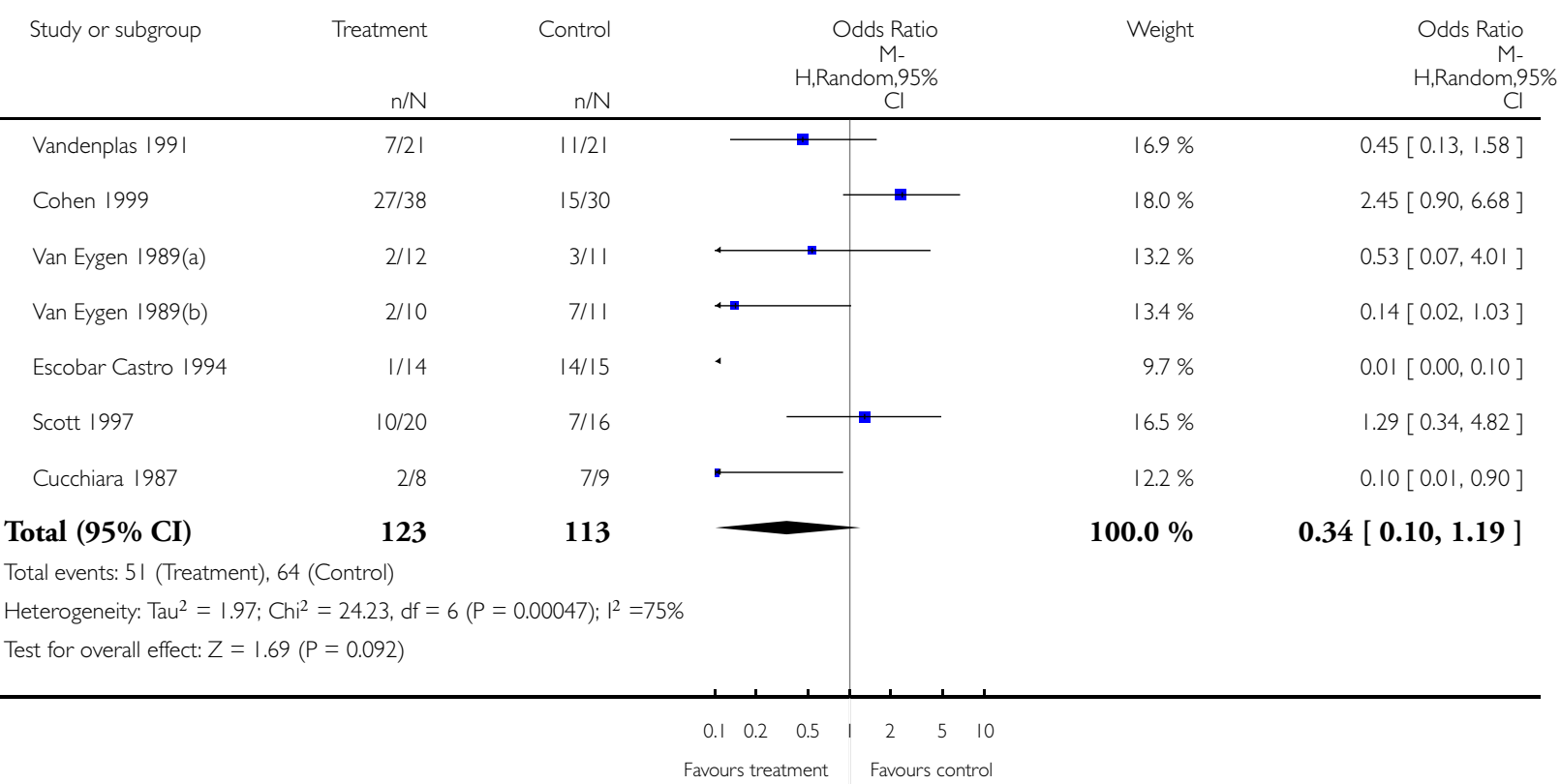




\section{Analysis I.2. Comparison I Main analysis for Cisapride vs placebo, Outcome 2 Reflux index.}

Review: Cisapride treatment for gastro-oesophageal reflux in children

Comparison: I Main analysis for Cisapride vs placebo

Outcome: 2 Reflux index

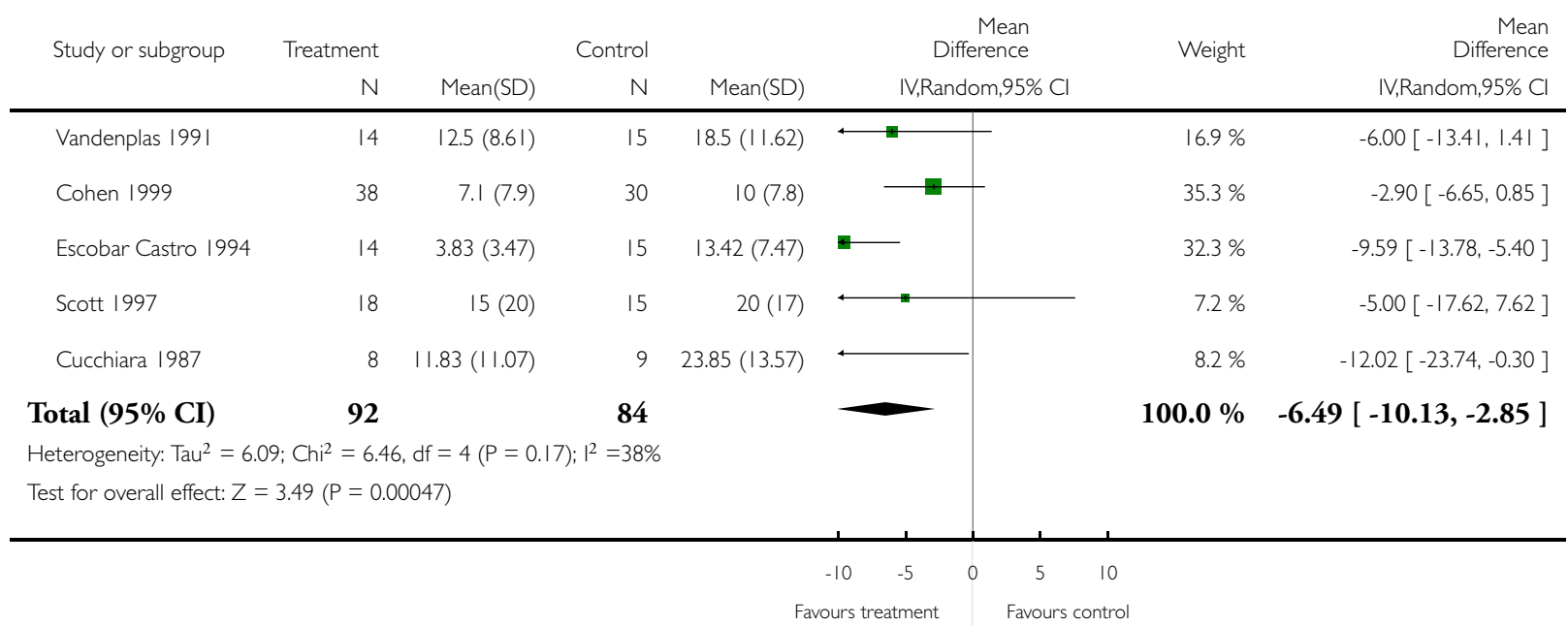




\section{Analysis I.3. Comparison I Main analysis for Cisapride vs placebo, Outcome 3 Adverse events.}

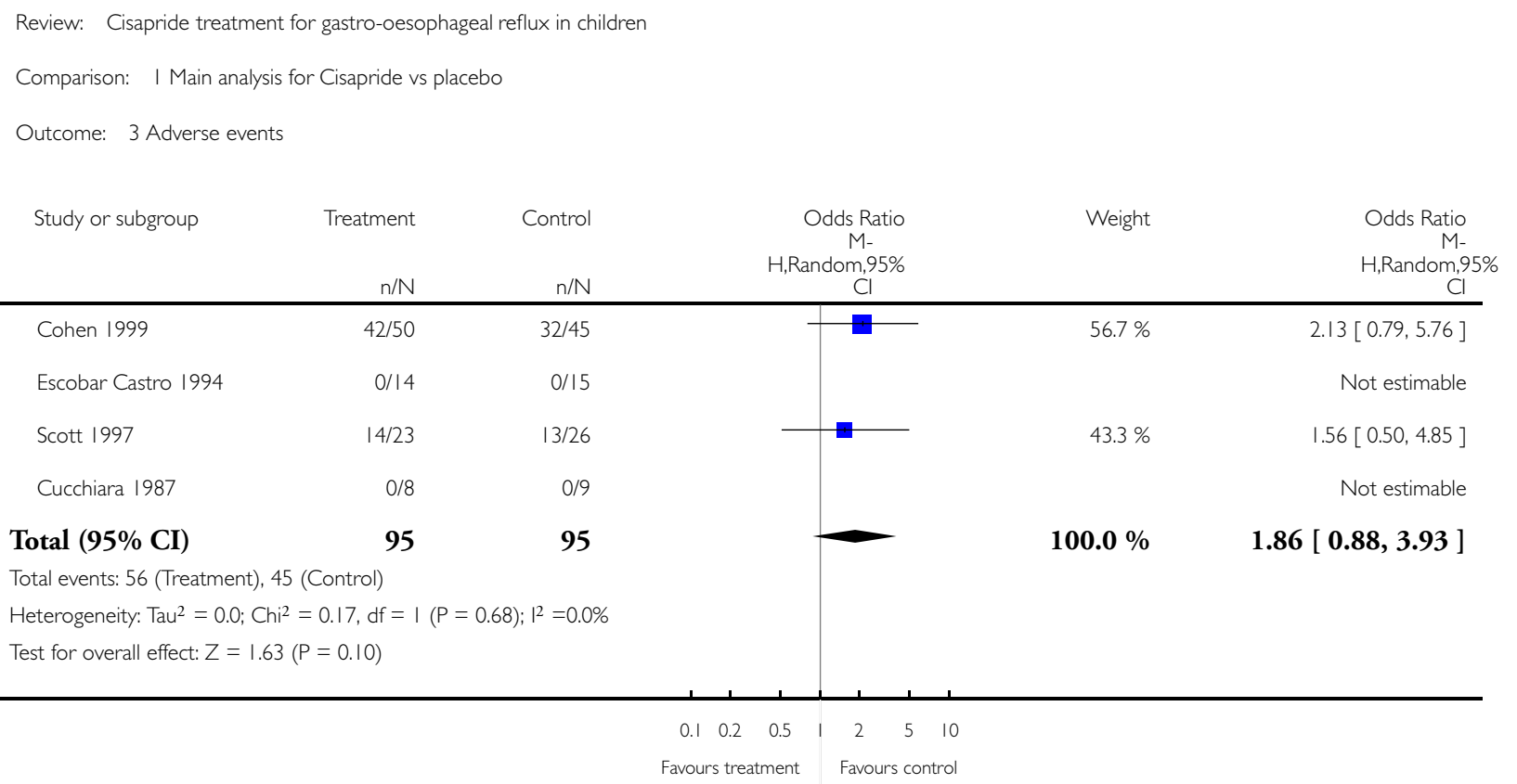

Analysis 2.I. Comparison 2 Main analysis for Cisapride vs Gaviscon/Carobel, Outcome I 'Worse, same or slight improvement' vs 'moderate or excellent improvement'.

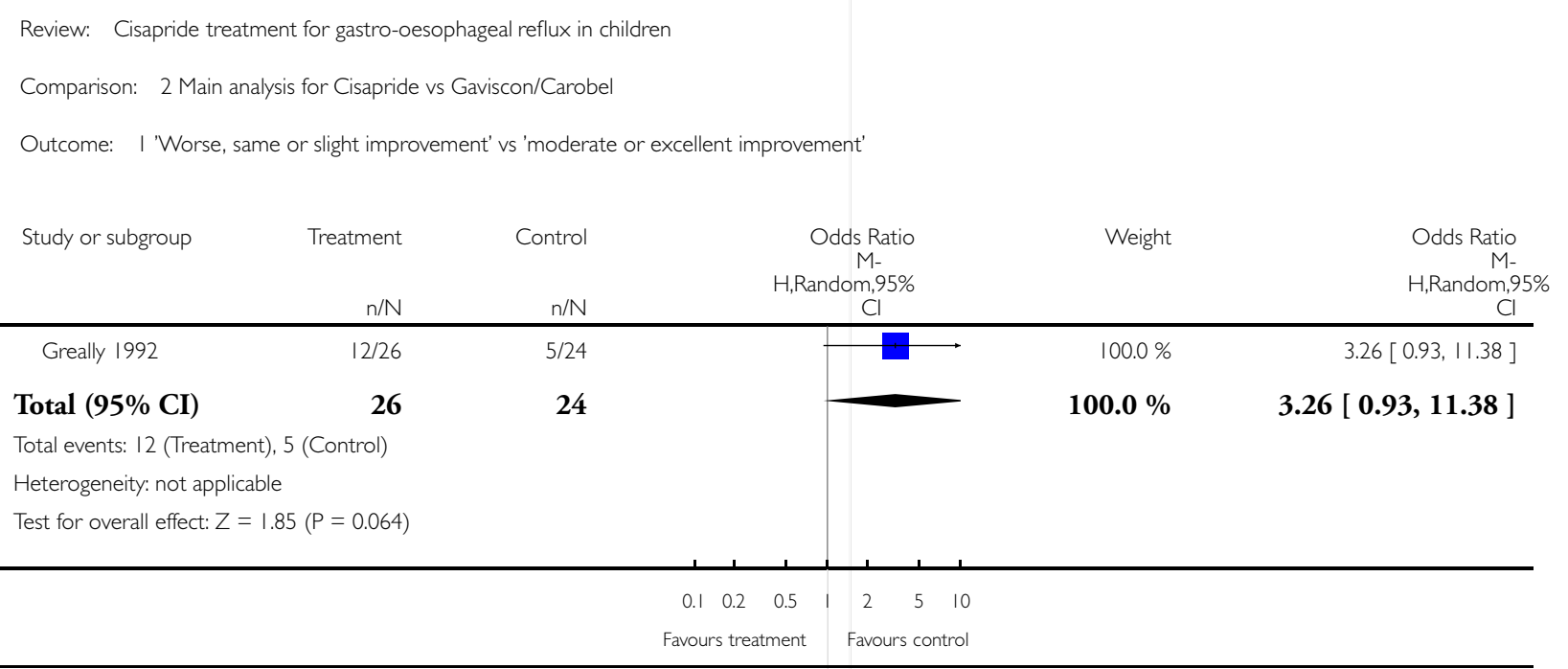




\section{Analysis 3.I. Comparison 3 Sensitivity analyses for Cisapride vs placebo, Outcome I Best case scenario.}

Review: Cisapride treatment for gastro-oesophageal reflux in children

Comparison: 3 Sensitivity analyses for Cisapride vs placebo

Outcome: I Best case scenario

M-

H,Random, $95 \%$

$\begin{array}{lll}\text { Cohen } 1999 & 27 / 50 & 30 / 45\end{array}$

$\mathrm{Cl}$

Weight

Odds Ratio

H,Random, $95 \%$

Cohen 1999

$\longrightarrow$

Cl

Cucchiara 1987

$2 / 10$

$8 / 10$

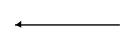

Escobar Castro 1994

I/15

$14 / 15$

$+$

Scott 1997

10/23

$17 / 26$

Van Eygen 1989(a)

$2 / 12$

$3 / 11$

Van Eygen 1989(b)

2/14

$13 / 17$

Vandenplas 1991

$7 / 21$

$|1 / 2|$

Total (95\% CI)

145

145
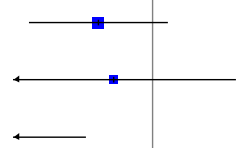

$+$

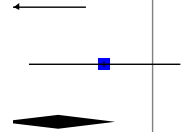

$10.9 \%$

$7.8 \%$

$18.2 \%$

$11.9 \%$

$12.9 \%$

$17.5 \%$ $0.59[0.26,1.35]$

Total events: 5 I (Treatment), 96 (Control)

Heterogeneity: $\mathrm{Tau}^{2}=1.00 ; \mathrm{Chi}^{2}=16.80, \mathrm{df}=6(\mathrm{P}=0.0 \mathrm{I}) ; \mathrm{I}^{2}=64 \%$

Test for overall effect: $Z=3.20(P=0.0014)$

$\begin{array}{lllllll}0.1 & 0.2 & 0.5 & 1 & 2 & 5 & 10\end{array}$

Favours treatment Favours control 


\section{Analysis 3.2. Comparison 3 Sensitivity analyses for Cisapride vs placebo, Outcome 2 Worst case scenario.}

Review: Cisapride treatment for gastro-oesophageal reflux in children

Comparison: 3 Sensitivity analyses for Cisapride vs placebo

Outcome: 2 Worst case scenario

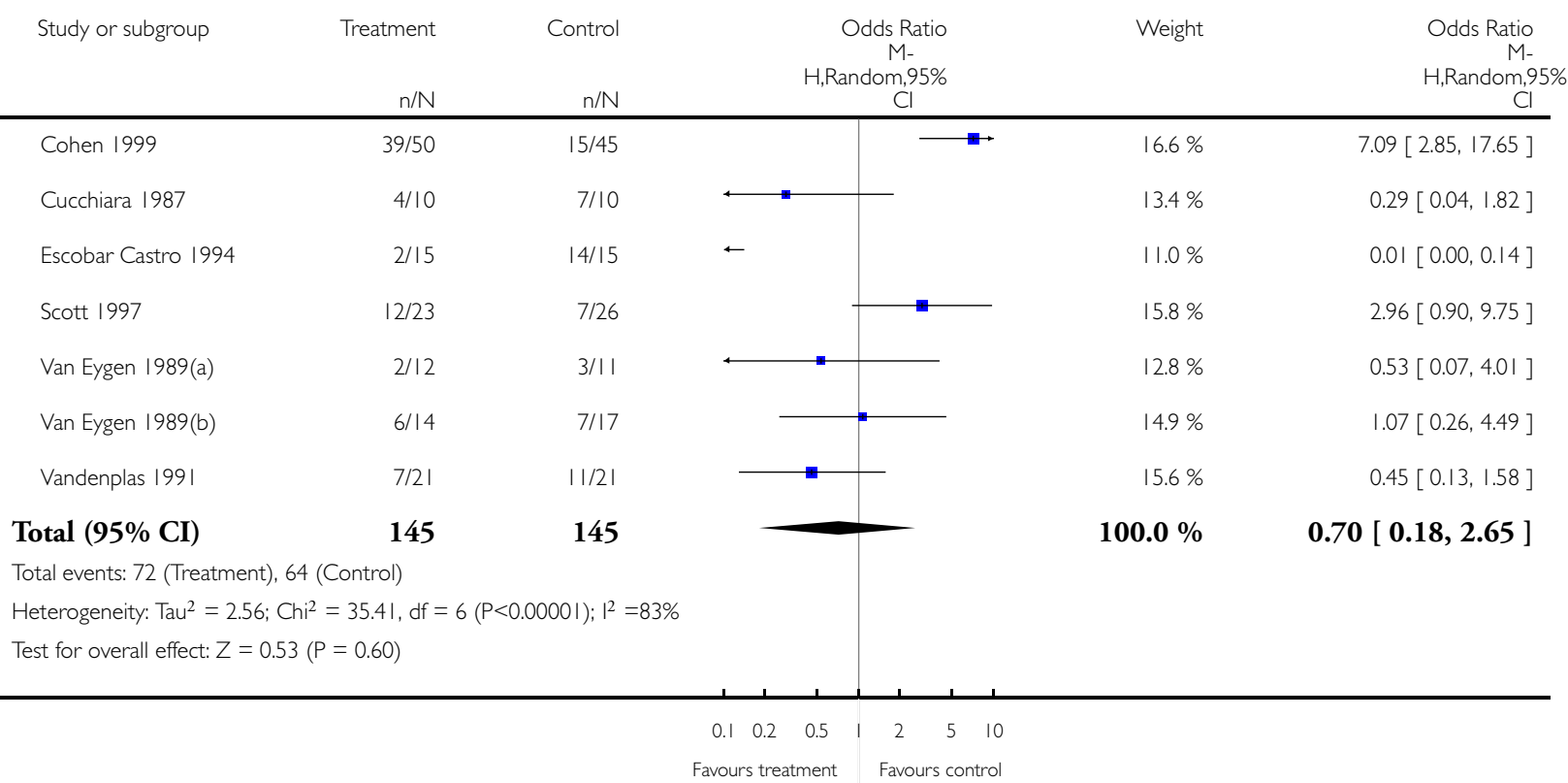


Analysis 3.3. Comparison 3 Sensitivity analyses for Cisapride vs placebo, Outcome 3 Change in outcome definition: 'any symptoms' vs 'no symptoms' at end of treatment.

Review: Cisapride treatment for gastro-oesophageal reflux in children

Comparison: 3 Sensitivity analyses for Cisapride vs placebo

Outcome: 3 Change in outcome definition: 'any symptoms' vs 'no symptoms' at end of treatment

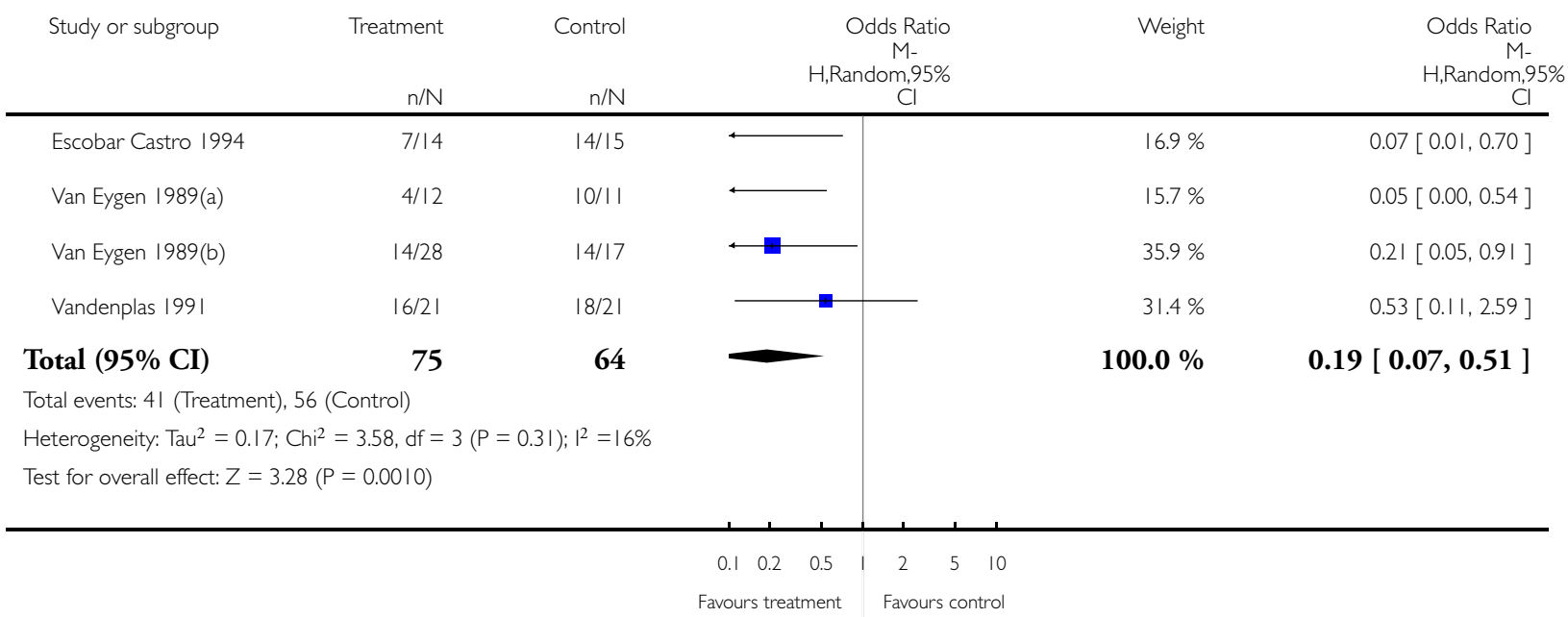

\section{WHAT'S NEW}

Last assessed as up-to-date: 12 June 2006.

Date Event Description

30 October 2008 Amended Converted to new review format.

\section{H I S T O R Y}

Protocol first published: Issue 1, 2000

Review first published: Issue 3, 2003 


\section{CONTRIBUTIONSOFAUTHORS}

All reviewers contributed to the design of the study, the development of the protocol, to the writing of the updated version of this review.

\section{DECLARATIONSOF INTEREST}

None known.

\section{SOURCES OF SUPPORT}

\section{Internal sources}

- Systematic Reviews Training Unit, UK.

\section{External sources}

- No sources of support supplied

\section{NOT E S}

All authors contributed to the overall design of the study and the development of the protocol for study inclusion and data extraction.

\section{N D EX TERMS}

\section{Medical Subject Headings (MeSH)}

Anti-Ulcer Agents [*therapeutic use]; Cisapride [*therapeutic use]; Gastroesophageal Reflux [*drug therapy]; Gastrointestinal Agents [*therapeutic use]; Infant, Newborn; Randomized Controlled Trials as Topic

\section{MeSH check words}

Humans; Infant 